\title{
"Being-in-the-World- Hispanically": A World on the "Border" of Many Worlds
}

\author{
Translated by ALEXANDER STEHN
}

\section{TRANSLATOR'S INTRODUCTION}

The abbreviated world-history of the hispano presented by Enrique Dussel in the essay that follows may seem strange in the context of the discipline of comparative literature, where such sweeping narratives are generally met with an understandable skepticism. For this reason, I begin by contextualizing the essay in terms of Dussel's larger attempt to develop a "transmodern" understanding of identity that incorporates the emancipatory message of modernity while purging it of its Eurocentric racism. ${ }^{1}$ Instead of a modernity centered in Europe and imposed as a global design upon the rest of the world, Dussel argues for a multiplicity of decolonizing critical responses to Eurocentric modernity from heretofore peripheral cultures and peoples around the world. Dussel's transmodern project is thus neither a premodern attempt to provide a folkloric affirmation of an imagined common past nor a reckless postmodern project that affirms only incommensurable difference. In fact, one could argue that some version of Dussel's transmodern project is often assumed as an unstated premise or perhaps even as an ideal goal for the comparatist enterprise. What besides "transmodern worldhood" (Dussel's term) could better provide the hermeneutic horizon for the practice of comparing literatures and cultures across all manner of times and places? As Djelal Kadir has suggested while discussing Dussel, the discipline of comparative literature "emerges from and institutionalizes this 'step towards a transmod-

\footnotetext{
${ }^{1}$ For Dussel's most recent discussion of his transmodern project, see "Transmodernity and Interculturality," in Ramón Grosfógel, Nelson Maldonado-Torres, and José David Saldívar, eds., Unsettling Postcolonial Studies: Coloniality, Border Thinking, and Transmodernity (Durham: Duke UP, forthcoming). -Trans. 
ern worldhood."'2 In effect, Dussel-who is himself situated on the border of many linguistic, cultural, and disciplinary worlds - offers us an interesting model for approaching interamerican studies as a form of global studies, and something like his model seems to underlie this volume's call for papers that "contemplate the Americas as a plural and yet sometimes integral entity, that weigh vast differences against shared histories, and that manage to connect cultures and languages across borders and boundaries of all kinds." At the very least, Dussel's attempt to see the world, its history, and its various peoples (especially hispanos) as part of a single world-historical system (that nonetheless remains a pluriverse) is fundamentally comparative. ${ }^{3}$

Of course, given his disciplinary home in philosophy, Dussel's overarching aims are more systematic than comparative. While his intellectual production spans the disciplines of political science, theology, history, economics, and Latin American studies (among others), Dussel self-identifies primarily as a philosopher of liberation. In his own words,

The Philosophy of Liberation that I practice . . regarding all types of oppression on the planet (of women, the discriminated races, the exploited classes, the marginalized poor, the impoverished countries, . . . in short, the immense majority of humanity), begins a dialogue with the hegemonic European-North American philosophical community... [with the] poverty of the greater part of humanity as a fundamental philosophical and ethical theme. (The Underside of Modernity vii)

One might reasonably expect that a philosophy seeking to diagnose and remedy the unjust suffering of the "immense majority of humanity" would be widely known (and even more widely disputed), but this is not the case despite Dussel's tireless attempt to create such dialogue. ${ }^{4}$ The contemporary intellectual manifestation of ancient Hellenocentrism is the Eurocentrism that treats even the ideas of the "third world" - which, as Dussel rightly notes, actually constitutes the "two-thirds world"as backward. Dussel writes in Spanish, a "barbaric" language to the ears of most English-, German-, and French-speaking "Greeks" of the hegemonic philosophical academy (see Dussel, History 20; and Mendieta's introduction to Underside of Modernity). Moreover, Dussel's philosophical interests in liberation theology and Marx (both manifestations of his concern for the ways in which many of the Earth's peoples have tried to make sense of their suffering and bolster their resistance) seem unfashionable for socio-economic, political, cultural, and historical reasons that extend far beyond the scope of the disciplinary strictures of philosophy. To do justice to Dussel's philosophy would thus require a lengthy discussion of everything

\footnotetext{
${ }^{2}$ See Kadir's 2007 keynote address to the International Forum at the annual meeting of the American Comparative Literature Association in Puebla, Mexico: "The Genesis of Comparative Literature: A Mexican Tributary," available at www.acla.org/acla2007/kadir_forum.pdf. Kadir is concerned with both the opportunities and the dangers that arise from the institutionalization of transmodern worldhood. - TRANS.

${ }^{3}$ Dussel wants to help create a transmodern pluriverse-an intercultural global system that contains many universes engaged in just exchange — rather than a globalized universe in which unity is achieved through domination. See thesis eighteen in his Twenty Theses on Politics, trans. George Ciccariello-Maher (Durham: Duke UP, 2008).- Trans.

${ }^{4}$ Eduardo Mendieta, who has edited and translated many of Dussel's works, has speculated about why Dussel is relatively unknown in North American philosophical circles. See Mendieta's introduction to Dussel, The Underside of Modernity: Apel, Ricoeur, Rorty, Taylor, and the Philosophy of Liberation, trans. Eduardo Mendieta (Atlantic Highlands: Humanities Press International, 1996), xii-xiv. The volume's essays clearly demonstrate Dussel's commitment to dialogue with leading European and North American philosophers.- TRAns.
} 
from the ways in which his philosophical views are inseparable from his personal experience to the ways in which liberation philosophy is situated in the geopolitics of knowledge. ${ }^{5}$ Paying attention to the diverse currents running through both Dussel's biography and the parts of the world referred to as Latin America would also illuminate his attempt to place the present-day life of hispanos in a global historical context. Here, however, I focus upon the essay's philosophical background.

Dussel offers a Heideggerian analysis of "being-in-the-world" for a human being identified, or self-identifying, as hispano. I have chosen to leave each occurrence of the Spanish term hispano untranslated in order to forestall familiar classificatory systems of race and/or ethnicity. Dussel's use of the word does not coincide with the English noun "Hispanic," which, as Dussel suggests in a footnote, has its own ambiguous and problematic genealogy. Nor does his technical use of hispano coincide with conventional Spanish usage, because he aims at deconstructing the everyday understanding of the term in order to subject it to rigorous philosophical development. In other words, Dussel does not intend to provide yet another description of who the hispano is (as though the identity of hispanos was pre-determined by race, history, or culture) but rather to develop a description of how hispanos live creatively given a remarkably multifaceted history. For Dussel, existing as a hispano is a particular way of being human, and the hispanic-being (ser-hispano) is a particular mode of the human being (ser humano). Given Dussel's modal analysis, I translate ser-hispano in the essay's title as "being-in-the-world-hispanically." The italics are not for emphasis, but instead mark the technical sense of the adverbial and adjectival forms of hispano. For instance, in rendering "communidad hispana" as "hispanic community," I leave hispanic in italics and lower case so that the adjective will be read as a term whose meaning is under development, and I treat parallel terms like anglo in the same way.

In order to develop a preliminary understanding of how Dussel's essay attempts to illuminate the identity of the ser-hispano, let us consider the following key passage:

The hispano, like every human being, lives (ex-ists) inevitably in a "world." His/her "being-in-theworld" has a "world" that has subsumed "many" worlds whose histories are not chronologically simultaneous but have instead unfolded with different rhythms and in diverse places, developing distinct contents. We name the resulting horizon "being-in-the-hispanic-world" as a concrete, current, and complex facticity whose intercultural riches converge to form an identity. This identity is always in formation, interstitial, born in a "border land" with such a wide range that hispanos pass from one tonality to another continuously without ceasing to experience themselves within hispanic solidarity.

Even though Dussel is describing what he takes to be a particular mode of ex-istence, the hispano is also like any other human being by virtue of living in a historical-cultural “world.” Heidegger names this ex-istence In-der-Welt-sein ("beingin-the-world") or more simply Dasein (literally, "being-there"), because human

\footnotetext{
${ }^{5}$ See Linda Martin Alcoff and Eduardo Mendieta, eds., Thinking from the Underside of History: Enrique Dussel's Philosophy of Liberation (Lanham: Rowan \& Littlefield, 2000), 1-26. In brief, Dussel was born and raised in Argentina, but he claims to have begun to truly understand Latin America and his position in it through the process of encountering other worlds: earning a doctorate in philosophy in Spain (1959), living in a community of manual laborers in a kibbutz in Israel (1960-61), traveling through the supposed birthplace of philosophy in Greece (1961), completing a second doctoral degree in history at the Sorbonne (1967), and then returning to Argentina to work as a professor of philosophy (1968). Not long thereafter, his house was fire-bombed by paramilitary forces (1973), and he was formally expelled from the University of Cuyo for criticizing a military dictatorship put in power under the recommendation of the CIA (1975). Since then, he has lived in exile in Mexico City. See also Walter Mignolo's "Dussel's Philosophy of Liberation: Ethics and the Geopolitics of Knowledge" (Alcoff and Mendieta 27-50).-TRANS.
} 
beings do not exist in the way that, for example, rocks do. A rock, when cast into a particular position by some force, simply remains there until moved by other forces. Human beings "thrown" into a particular historical-cultural location not of their own choosing begin to shape the spaces into which they were thrown. Dussel's analysis of the hispano attempts to portray broadly the diverse historicalcultural realities that constitute his or her "thrownness" (or facticity). Of course, these historical-cultural realities have a long, rich, and often hotly contested history, and this is what Dussel means when he writes that the "world" in which hispanos dwell is one that has "subsumed 'many' worlds." The process is neither linear nor complete, though it does constitute a horizon that Dussel names "being-in-thehispanic-world" (with reference to the world) and "being-in-the-world-hispanically" (with reference to the mode of ex-istence). The horizon metaphor is apt because it suggests infinite possibilities while simultaneously insisting upon the specifiable location and history of the ex-istence that creatively projects itself into the future. This allows hispanos (like every other people) to take stock of a diverse history, passing "from one tonality to another continuously without ceasing to experience themselves within hispanic solidarity."

The task that Dussel sets for himself, then, is to describe in admittedly broad and sweeping strokes the world-historical context for the hispano's particular way of being human. As Dussel notes, this is an attempt to move previous philosophical discussions of identity in America beyond idealism (José Vasconcelos), hybridity (García Canclini), and self-conflicted historicity (Octavio Paz). His analysis is comparative by virtue of the five historical-cultural "worlds" that overlap to form the "border" where the hispano dwells. By philosophically inflecting both Homi Bhabha's notion of the liminal spaces "in-between" standard categories of identity and the Cuban anthropologist Fernando Ortiz's analysis of the "transculturation" that results from cultural exchanges and displacements, Dussel describes the "world" and "ex-istence" of hispanos in terms of the diverse cardinal and cultural directions and dynamics that have produced new ways of life, new patterns of localization, and ever-evolving identities. In sum, Dussel revises traditional philosophical notions of human universality by combining them with the recognition of irreducible difference in order to think of group identity as a diversality, ${ }^{6}$ thereby establishing the imperative of constituting a broader hispanic "we." As Dussel writes in this essay, translated here for the first time, such an identity is "neither substantialist nor essentialist but instead creates its own elements dialectically through the continuous integration of new challenges in the very process of history."

Nonetheless, some readers may find Dussel's discussion of the "worlds" from which hispanos have historically emerged to be problematic or even offensive. For instance, one might ask why the "fourth of worlds" constituted by the AfroCaribbean receives such brief treatment in comparison with the others, especially since it relies so heavily on themes like sensuality and dancing, stereotypes associated with the white racism that Dussel attempts to undermine. Likewise, one may wonder about the strategic wisdom of Dussel's attempt to rid derogatory terms of their sting by historically re-contextualizing them. He does this, for instance, when

${ }^{6}$ I borrow the term diversality from Walter Mignolo (Local Histories/Global Designs [Princeton: Princeton UP, 2000]), who adapted it from its original incarnation in the work of Caribbean writer and essayist Edouard Glissant.-TRANS. 
he refers to the Visigoths bound for the Byzantine Empire as "wetbacks," since they crossed the Danube River. Finally, one might be troubled by the fact that the main agent in Dussel's story, the hispano, remains grammatically masculine until well into the essay. Obviously, Dussel does not think that being hispanically is an exclusively masculine way of being-in-the-world, but in his semi-mythical mode of presentation, the hispano does not appear as both grammatical genders (hispano/a) until the third section, which describes the "third of worlds" as a kind of synthesis between the "first of worlds" (Malinche the indigenous mother) and the "second of worlds" (Cortés the Spanish father). ${ }^{7}$ Unlike most essays, where the subject to be discussed is articulated at the outset in order to serve as the foundation upon which the rest of the inquiry is built, Dussel's essay uncovers the identity of its subject as it proceeds. The disagreements occasioned by this essay, no less than the agreements, will thus serve Dussel's ongoing project of surveying the polyphonic identity of the ser-hispano.

The Pennsylvania State University

\footnotetext{
${ }^{7}$ I am therefore translating the possessive pronoun $s u$ associated with hispano (and parallel terms like $a n g l o)$ as "his/her" since su serves as the equivalent for "his," "her," "its," and "their" in English. Of course, this still does not solve the gender problem, which Dussel does not explicitly problematize here, although he does have a long history of dialogue with feminists, who have often led him to transform his views in light of their criticisms. See, for instance, Ofelia Schutte, "Origins and Tendencies of the Philosophy of Liberation in Latin American Thought: A Critique of Dussel's Ethics" (Philosophical Forum 22 [1991]: 270-95). On pages 9-10 of The Underside of Modernity, Dussel retracts several of the ethical positions for which Ofelia Schutte criticized him on feminist grounds. - TRANS.
} 


\section{"BEING-IN-THE-WORLD-HISPANICALLY": A WORLD ON THE "BORDER" OF MANY WORLDS}

$I^{2}$

DO NOT INTEND TO propose a utopic "cosmic race" like that of José Vasconcelos, or the "hybridity" of Néstor García Canclini, or a history interpreted literally like that of Octavio Paz in The Labyrinth of Solitude, but rather a moving discovery of the hispano as "located" creatively "in-between" many worlds that continuously constitute a historical identity on the intercultural "border." 8 This identity is neither substantialist nor essentialist but instead creates its own elements dialectically through the continuous integration of new challenges in the very process of history. But this historical experience is also normative: it must be discovered and affirmed in its dignity, especially when the present state of the hispanic community sets out from a negative self-evaluation of its own existence. The cultural complexity of being-in-the-world-hispanically must be lived subjectively, by means of active and creative intersubjectivity, which accepts challenges and integrates them rather than living them merely as a dispersion or tear.

My strategy in this contribution, originally presented in a seminar at the University of Pittsburgh, is situated in a committed pedagogical horizon that attempts to be comprehensible to a hispano who is neither a college student nor an academic, but rather from the social base to which I have spoken many times, from California to North Carolina at Duke, from New York to Chicago, and in many other North American universities and cities. When the hispano discovers his/her complex, constitutive history, he/she reacts to the comments with a certain annoyance: "Why didn't they ever tell us this? Why have they hidden our history from us in the educational system and other North American institutions?" I have responded more or less as follows: "It would be difficult for an elementary school, high school, university, labor union, or religious group to demonstrate to the hispano an existence ${ }^{9}$ so rich and ancient and with such present potential. The anglo zealously defends his/her cultural, political, and religious superiority." In this contribution, then, I wish to maintain a colloquial tone comprehensible to the average common sense of hispanos in the United States; I will treat this subject like an outline for a course, seminar, or lecture for hispanos interested in developing their own "historical-critical consciousness."

\footnotetext{
${ }^{8}$ The "in-between" of Homi Bhabha; see The Location of Culture. This "border" is not a line but a dense territory in the sense of Gadamer's "fusion" of horizons. It is more a "space" than a limit, a "space" between many worlds that the (intersubjective) subjectivity of the actor inhabits simultaneously. The actor articulates all of them, each one being both "my world" and "our world," in the solidarity of the Hegelian "being-at-home" [zu-Hause] but "exterior" to the hegemonic world of the anglos, in (Levinasian) "alterity."

${ }^{9}$ In this instance, in the title, and in this "paper" generally, the word "ex-istence" will be a technical term with a Sartrean or Heideggerean meaning ("ex-": the point of origin; "-istence": transcendence or "being-thrown" in the "world").
} 
The hispano, ${ }^{10}$ like every human being, ${ }^{11}$ lives (ex-ists) inevitably in a "world." His/her "being-in-the-world" (Heidegger $§ 12,78 f f$ ) has a "world" that has subsumed "many" worlds whose histories are not chronologically simultaneous but have instead unfolded with different rhythms and in diverse places, developing distinct contents. We name the resulting horizon "being-in-the-hispanic-world" as a concrete, current, and complex facticity whose intercultural riches converge to form an identity. This identity is always in formation, interstitial, born in a "border land" with such a wide range that hispanos pass from one tonality to another continuously without ceasing to experience themselves within hispanic solidarity. The hispano can be an indigenous Guatemalan in Chicago, a Mexican mestizo in San Diego, a white criollo Uruguayan in Washington, an Afro-Caribbean Puerto-Rican in New York or Cuban in Miami, a mulato from the Dominican Republic in Houston, to name a few. Many worlds in one world. A world that today in the hegemonic North American society is despised, dominated, impoverished, and excluded (beyond the horizon of the acceptable anglo world, beyond the "line" of Heideggerean ontology, on the border where non-being, the non-sense of Levinasian alterity commences). They are the last ones on the social, cultural, and epidemiological scale (a higher percentage of them have AIDS, for example). The "hispanic world" is like a phantom, a specter that roams around in "exteriority" but has recently begun showing itself with a new face, acquiring new rights thanks to its struggle for recognition of a distinct existence. I believe that this struggle could serve as a model of the narrative I will present after drawing a basic map of the history and territorialization of this "hispanic world." Teachers, leaders, and militants in communities might use this sketch to affirm their frequently under-appreciated dignity. My narrative is intended to be an ethical-pedagogical one; I do not propose to denigrate the anglo but simply to demonstrate and affirm dialectically the historical values of the hispano. It may seem tendentious, but it is not altogether bad to be an apologist for those who are depreciated, persecuted, and marginalized. I imagine each one of the five "worlds" that I suggest as a circle that coincides with the others around the hispano, who nonetheless maintains a certain exteriority with reference to the hegemonic world. Every hispano lives in and through these worlds to a greater or lesser extent.

It may be worthwhile to begin by recounting an anecdote, an experience I had years ago at the University of Notre Dame. While filling out an administrative form for my position as a professor, I had to respond to a question about my "ethnicity," which disconcerted me as obviously racist. The form began with the questions: "Are you White (non-Hispanic)?" "Are you African-American (non-Hispanic)?" "Native-American (non-Hispanic)?" and finally, "Are you Hispanic?" I asked the secretary, "What do you think?" Hearing my "accent" in English, she asked me, "You're from Mexico? Put Hispanic."12 Thus was I classified by (under) the possible "ethnicities." With this anecdote, I open the present historical-cultural reflection.

\footnotetext{
${ }^{10}$ Twenty years have passed since "Hispanics" were the white citizens of New Mexico who did not want to be confused with "Chicanos." Later, they were called "Latinos," but now I believe that the term "Hispanic" is being imposed. Of course, the question of the political opportunities offered by this cultural and political community denomination remains to be considered.

${ }^{11}$ Heidegger names this mere ex-istence "Dasein." See Being and Time $§ 9 f f, p p .67 f f$.

${ }^{12}$ At the time, I was an Argentine citizen and resident of Mexico, a fourth-generation Latin American whose origins are part German and part Italian.
} 


\section{The "First of Worlds."13 On the "Mother's" Side: The Eastern Extreme of the Far East}

When one encounters a Mexican in Los Angeles or San Jose, even if one quickly realizes that the person is, for example, a Zapotec from Oaxaca who speaks his/her Amerindian language and perhaps will shortly express himself/ herself more fluently in English than in Spanish, one discovers a hispano who differs from many others who identify with this same cultural, historical, and political community.

In effect, the hispano always has a certain constitutive, originary reference to the Amerindian cultures. For one who belongs by race, language, culture, religion, or history to an indigenous community, this belonging is obviously much stronger, but in any case, hispanos react spontaneously to an indigenous person from Latin America as a member of their own community. This can be observed in the murals that cover numerous walls in the hispanic neighborhoods of North American cities (the art simultaneously so Aztec and so Mexican, which inspired Rivera, Orozco, and O'Gorman at the beginning of the twentieth century). The indigenous person frequently appears as a symbolic moment in these historical representations, not as a depreciated "native" but as a foundation upon which a historical identity is built. It is as if the painters of these murals wanted to say: "We have always been here! We come from Aztlán!" This referential component is essential. The hispano (whether indigenous or mestizo) relates to America as his/her "own" ancestral, originary continent (geographic and cultural) through "Malinche," his/her "mother," who provides the link with "mother earth" ("Pacha Mama" of the Andes, "Coatlicue" of the Valley of Mexico, or "Tonantzín": our little mother). This American land was originally hispanic on the mother's side. It was not the "vacant" land of John Locke or Walt Whitman but instead full of historical-cultural significance. More than anyone else, the indigenous person merits the name "American" (americano).

As we have explained in other works concerning the movement of our native peoples,${ }^{14}$ humanity carried out a long process of civilization creation in the AfroAsian continent, beginning with the Neolithic cultures in present-day Turkey, with cities as old as the seventh millennium BCE in Mesopotamia, passing through Egypt in the fourth millennium, and appearing in the civilizations of India and China. Contrary to the Eurocentric Hegelian opinion, this was the "long march" towards the East-from the West to the East. We want to insert the origin of the cultural history of hispanos into this movement. On their maternal side, they were born in the eastern extreme of the Far East on the Asian continent-the ultimate West for America, beyond the Pacific Ocean, the central reference for the Polynesian civilizations to which the Amerindian cultures owe so much. From there, after tens of thousands of years of traveling on foot by way of the Bering

${ }^{13}$ I write "First of Worlds" and not "First World" for obvious reasons in order to avoid a geopolitical confusion. [Dussel reverses the normal Spanish order of noun and adjective, writing "mundo primero" ("world first") instead of "primero mundo" ("first world"). I have substituted "first of worlds" for the awkwardly literal "world first" and have done the same for the worlds that follow.—TRANs.]

${ }^{14}$ See Hipótesis, El encubrimiento del Otro, and Ética de la Liberación 15-98. Full-text versions of these first two works (as well as many others in both English and Spanish) are available at $<$ http://www .enriquedussel.org/> 
Strait, always moving towards the east, they began entering America from the north (Alaska), arriving twenty thousand years later in the south (Tierra del Fuego) by the most diverse migratory routes from eastern Asia and the western Pacific. Today we are sure that all of these originary American cultures were Asian, that they passed through Mongolia, Siberia, and the islands and coasts of the western Pacific, driven out by the fiercest of peoples and fleeing towards the north. The Eskimos were the last to arrive, and they remain in Siberia and Canada to this day, perhaps originally driven out by Turkish peoples. The racial similarity, down to facial features, of our indigenous peoples with the inhabitants of Mongolia, Indonesia, the Philippines, Polynesia, and Micronesia is widely recognized.

The important thing for a reconstruction of the "historical-critical consciousness" of hispanos is that their native ancestors not be situated as defeated people from "nowhere," as if they fell from heaven and were just here in America on the beaches of some Caribbean islands "awaiting" the arrival of Christopher Columbus, the "discoverer" who would invest them with a "place" in history. They were the first inhabitants of America and created great urban civilizations similar to those of the Egyptians, the Mesopotamians, the people of the Indus Valley, or the people of the Yellow River, chronologically continuing the journey towards the east. Arriving from maternal Asia, they had already "discovered" the entire continent when the European invasion began in $1492 . .^{15}$

The hispano must experience existentially (subjectively and intersubjectively) the reality of having been on the American continent, in its valleys, rivers, mountains, jungles, etc., from the furthest reaches of human history, from millennial antiquity, "before" all of the subsequent invasions. Hispanos should know the dignity of being "the first," "the oldest," with respect to all those who would arrive "later." This would neither demean them nor make them superior, but facilitate their experience of the free gift of receiving those who arrived from other "worlds." Hispanos offered food (the "turkey" is an American, an Amerindian animal) to the European souls who disembarked hungry, and who would later celebrate by remembering the food provided to them, but forget the assassination with which they repaid those who so generously gave them hospitality with their own scarce goods in their own land.

Hispanos must know and appreciate the Amerindian world, not only the existence of nomadic communities (from the north of the United States down to the south of the Incan empire) or the planters of the Caribbean and Amazonian grasslands, but also the imposing urban cultures of "nuclear America": the Mayans, Aztecs, Chibchas, Incas, etc. The establishment of these civilizations, their historical feats, their foundational texts, their magnificent cultural, political, religious, esthetic, commercial, economic, and military structures must be recognized. Hispanos should study these cultures as a moment in the constitution of their own identity, which goes on changing, growing, and developing in their steps through space and time. In this case, memory is a fundamental moment in the creation of an identity of solidarity.

${ }^{15}$ This experience of "arriving" in Amerindia from the west should be lived by hispanos as an ontological experience of the first order. 


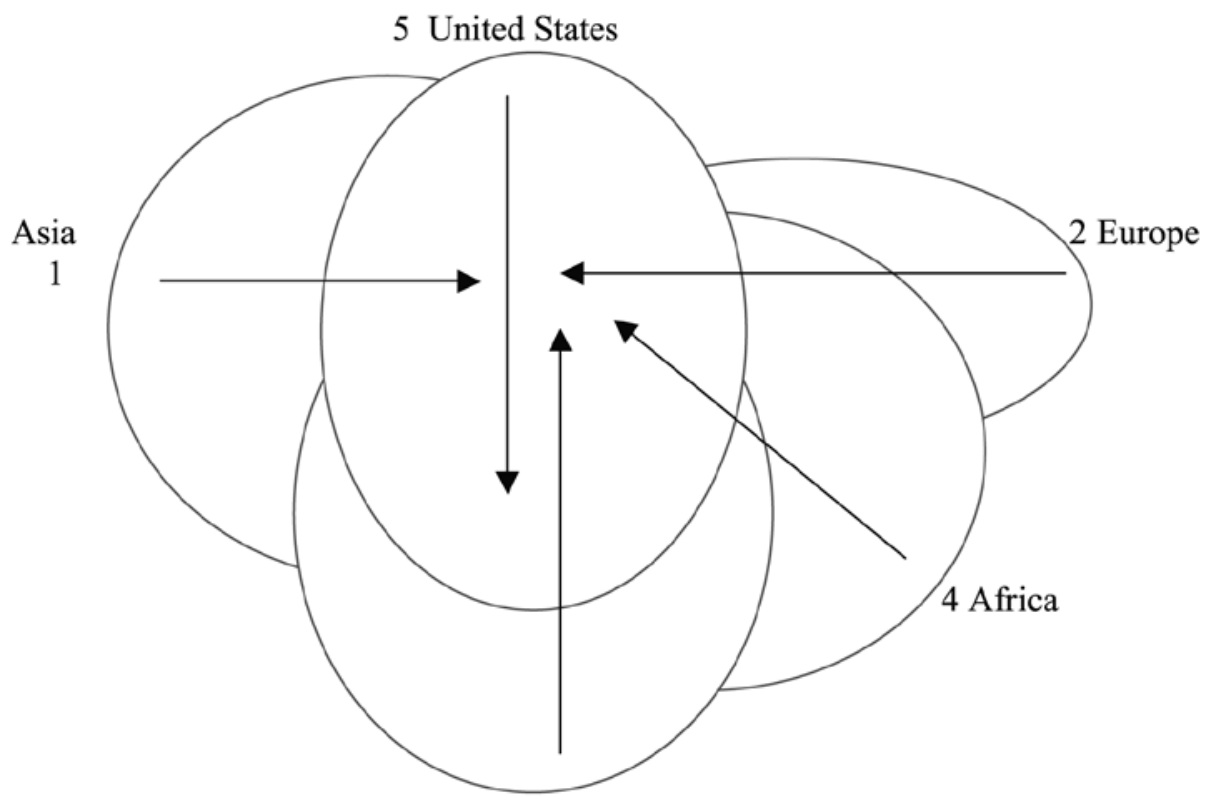

3 Latin America

Figure 1. The Hispano: A "World" as "Border Land" Between (In-Between) Many "Worlds"

(1) From the eastern extreme of the Asian Far East; (2) From the western extreme of the European Far West; (3) The far north of the Latin American South;

(4) From the west of Africa; (5) The far south of the Anglo-Saxon North.

\section{The "Second of Worlds." On the "Father's" Side: The Far West of the Western Extreme}

In the fortieth century BCE, on the north of the Black Sea, there were peoples who smelted iron, domesticated the horse, and buried dead riders together with their horses. ${ }^{16}$ This was the "Kurgan" culture (in southern Russia). Centuries later we observe an aggressive bronze statue of a rider with an iron sword in his hand, the figure of Francisco Pizarro in the main plaza of Lima, marking the arrival in America of the culture of the horse and iron. It is the history of a people that arrived in our continent by moving from east to west.

Spain and Portugal were the finis terrae (the end of the world) of this ancient system, which, beginning with Japan and China in the east, culminated in the

${ }^{16}$ These riders arrived from China and India (by way of Kabul), reaching the Medes, Persians, Greeks, and Latins. They were the first "cowboys," who, after crossing the Arabian deserts, arrived in Andalusia as Muslim vaqueros. From there, they passed through Mexico towards the south of the continent as llaneros in the Colombian plains, and as gauchos in the Argentinean pampas. Finally, they moved north through Mexico to the south of what is now the United States. Their history is already the history of the "father" of hispanos. 
west with Europe. Spain was colonized by Phoenicians in the second millennium BCE and was a province of the Roman Empire at the end of the first millennium BCE. (The Indo-European language called "Spanish" was born in the Middle Ages during the Spanish "reconquest" of the Muslims, and it bears the closest resemblance to ancient Latin.) Spain would go on to shelter a Christianity whose plenitude (with Isidore of Seville) was replaced by the caliphate of Córdoba as cultural center (another Spanish glory that no other European country could boast), philosophical center (with Ibn-Rushd), and theological center (with Maimonides). At this time, the West obtained Latin versions of Greek works translated from Arabic or Greek itself, which in turn permitted the classical medieval thirteenth century in Paris. The "reconquest," which began in 718 in a skirmish that tradition calls the Battle of Covadonga, would last until January of 1492, when the kings of Castile and Aragon occupied Granada. This "reconquest" would be continued seamlessly as the "conquest" of America.

The Iberian countries had already begun the first Early Modernity in the fifteenth century. Spain, together with Portugal (which anticipated the Spanish undertaking by a century), would produce the opening to the Atlantic, thus constituting the "bridge" between the ancient world and Modernity. Spain and Portugal originated Modernity precisely with the "invasion" of the West Indies, the Abbia Yala of the Kuna Indians of Panama, inadequately called "America" in honor of the Renaissance figure Amerigo Vespucci.

The cultures of the far west (Europe) of the Afro-Asian continent were never "central" with respect to this gigantic civilized space. The connecting territory was the Persian empire (the Hellenists), then the Byzantine empire (the Sassanids), a region eventually occupied by the caliphate of Baghdad, the commercial "center" of the ancient system from the eighth to the thirteenth century, the five hundred years of classical Islamic culture. Europe was never hegemonic in this sphere. In fact, the north of Europe was submerged in the barbarism of the Germanic peoples until well into the Middle Ages. The fundamental pole of the entire continent, with the greatest population, culture, and commerce, was always China and Hindustan. They were connected to the Byzantine world by the Muslim commercial civilization, which stretched from the Philippines to Spain, passing through Málaga, the Mughal Empire, and the kingdoms of the Middle East, as far as Egypt and Morocco.

The hegemony of Genoa and Venice (both Byzantine) that had connected LatinGermanic Europe with the "ancient system" passed to Spain and Portugal by virtue of their being situated between the Mediterranean and the Atlantic, and because they achieved unity before any other country of northern Europe (Portugal in the fourteenth century and Spain in 1476 with the uniting of Castile and Aragon). Spain and Portugal initiated Modernity, not northern Europe as has been previously taught (an interpretation promulgated by northern Europe itself). The Italian Renaissance was merely the Mediterranean awakening, brought about by the fall of the Greek Constantinople, whereas Spain and Portugal inherited the Renaissance and opened the wider world of the Atlantic (the geopolitical center of Modernity). Still under the commercial hegemony of China and Hindustan, and against the Muslim Ottoman world that connected these powers with Europe, Portugal discovered the Atlantic southeast with the nautical school of Henry the 
Navigator, who opened Europe to the "Arab Sea" (the Indian Ocean). Spain did the same with the tropical Atlantic, connecting the Caribbean with Europe thanks to the Genovese Christopher Columbus.

The cultural collision of the easternmost part of the East (Amerindia) with the westernmost part of the West (the Iberian countries) is the most formidable intercultural confrontation in all world history. The land had already been completely occupied, but now humanity united in an embrace (fatal for the Amerindians) the entwining of Malinche and Cortés, "two worlds" of the many that constitute "the" hispanic world. Their meeting is incredible but nonetheless historical, and it was made flesh five hundred years ago. It is a cultural collision that the hispano carries in his/her culture, blood, and history, an embrace that the anglo cannot comprehend, experience, or appreciate. The hispano has an amazing American historical complexity, a European Latino for a "father" with behaviors befitting the Islamic refinement of Cordoba, Seville, and Granada, so far from the barbarity of Medieval Europe.

The Spanish presence in America since 1492 and that of Portugal in Brazil since 1500 preceded the Dutch and English invasion of the northern coasts of America by a century. It is the beginning of the first Early Modernity, the original deployment of the "World-System" about which Immanuel Wallerstein has spoken so accurately (see The Modern World System). Latin America (Amerindia plus Iberian countries) is modern from its origin. It suffers the Modernity that always begins with armed violence (in Latin America, Africa, and Asia), whose first sign is the "conquest" that begins in the Caribbean in 1492 and arrives at the Maule River in Chile in approximately 1540. "Nuclear America," which contained the majority of the continent's population, was occupied within fifty years.

Whether mestizo or criollo, the hispano comes into relation with a part of himself/herself when thinking about modern Europe. On the "father's" side there is the chauvinist Cortés who dominates the delicate indigenous princess Malinche in the correct interpretation of Octavio Paz's Labyrinth of Solitude, but the hispano relates nonetheless to the Amerindian cultures through his/her "mother," and also with the Spaniard, but not in the disparaging sense of the Latin Americans (the "royalists," the "gachupines"). I think that the hispano has a geopolitical interest in reminding anglos of their descent from the Spain that made England tremble with the "Invincible Armada" at the end of the sixteenth century. In fact, when Carl Schmitt wanted to give an example of the meaning of "enemy," he cited one of Cromwell's texts about the Spanish. ${ }^{17}$ The confrontation between hispano and anglo-saxon is many centuries old, beginning before the Roman Empire but becoming especially bitter in the sixteenth century with the Spanish hegemony in Europe. Unlike England in the Atlantic Europe of the North Sea, which was Germanic, medieval, never in contact with the great Phoenician, Egyptian, and Greek cultures, and only became a part of the Roman Empire very late, Spain was situated in the Mediterranean, and was one of the historical opponents of the anglo-saxons (in contrast to Portugal, which in many cases was subsequently allied with England against Spain). The hispano, then, on the "father's" side, awakens in the anglo many

\footnotetext{
${ }^{17}$ On September 17, 1656, Cromwell wrote: "The first thing therefore . . . is that: . . Being and Preservation. .. . Why, truly, your great Enemy is the Spaniard. He is a natural enemy . . by reason of that enmity that is in him against whatsoever is of God" (qtd. in Schmitt 67).
} 
"bad memories" (Shakespeare knew that the "One-Armed Man of Lepanto"18 initiated modern literature). The anglo cannot consider hispanos an inferior people but, on the contrary, must consider them a more ancient, more numerous, and more developed people (all this, of course, until the early seventeenth century, with the decline of Spain and the ascendency of England).

So the hispano should be conscious of the fact that his/her language, culture, and Baroque religion all have a European component that cannot be denied and must be integrated with his/her Amerindian past in order to constitute an inimitable historical personality. This "other" world, which the hispano lives as his/her own, creatively combines with and comes to enrich the "first."

\section{The "Third of Worlds." Like a "Brother/Sister" of "Mestizo/a" Descent: The Far North of the South}

The mestizo, the "pocho" in Los Angeles that Octavio Paz spoke about, is a racial and cultural mixture as old as Modernity. No other race or culture can take this dignity and this stigma away from the mestizo. Martín Cortés, the son of Malinche and the Spanish captain, would die in Spain, forgotten for reasons not attributable to war, thus demonstrating the destiny of a mestizo, a symbol of forgetting one's origin and the meaning of one's existence.

The hispano is a synthesis (the "third of worlds"), a brother/sister of the Latin Americans (who expanded into the "North"), a descendent of the first of worlds (Malinche), the second (Cortés), and the third, the criollo (a white European born in America and thus American). It was one of these young criollos who founded the Jesuit reductions (reducciones) (see Dussel, A History) after having rowed canoes through the immense and infinite rivers of guarani Paraguay, having eaten, slept, and dressed like the indigenous people of the region since childhood. The Jesuits in the reductions respected the customs of the Amerindians by going without private property, speaking Amerindian languages, and adopting local practices. The Spaniards who came from Europe could no longer understand the spirit of the hispanos (criollos) born on this continent. Hispanos are, for this reason, older "Americans" than those who would come later (by way of their indigenous "mothers" and the people born in these lands, whether mestizos or criollos-inhabitants of this continent since the end of the fifteenth century). The other groups who would subsequently arrive in New England (not only Africans but also Europeans from non-Anglo-Saxon regions) were fully conscious of being in a strange and already colonized land.$^{19}$ On the other hand, hispanos were fully conscious of the

${ }^{18}$ And it is not too much to recall that the battle of 1571, in which Miguel de Cervantes participated and where Spain defeated the Ottomans, is also the end of Spain's importance in the Mediterranean and the beginning of its uninterrupted hegemony over the Atlantic, the greatest geopolitical change of the last five hundred years, which Spain initiated. [Cervantes's left arm was permanently maimed while fighting in this famous battle, and he was especially proud of both his role in the battle and the resulting nickname mentioned by Dussel: El manco de Lepanto. - Trans.]

${ }^{19}$ It is interesting to remember, among so many histories, the Spanish Jewish communities that fled to Portugal after their unjust expulsion in 1492. From Portugal, some (like the family of Spinoza) set out in exile towards the United Provinces of Holland. From there, some went to the Dutch Caribbean colonies, for example, Curaçao. The wandering Jewish community ultimately moved to New Amsterdam in New Holland. This community would remain when New Amsterdam passed into England's hands, and it would transform itself into the Jewish community of New York long before the anglos. 
fact that these American lands were inhabited by them before any other group, including anglos. Hispanos were stripped of these lands, which were declared "vacant"; they were thus excluded from their own lands as the Canaanites were excluded from theirs when Joshua occupied Jericho, coming from the desert and having been a slave in Egypt.

The history of the Latin American side of the hispano develops as a colonial history from the Caribbean to terra firma, from Panama to Venezuela and Florida, heading south by way of the viceroyalty of Nueva Granada (northern South America, largely what is now Panamá, Colombia, Venezuela, and Ecuador) along the Pacific coast of Ecuador, Peru, and Chile, an area united by the mining of silver, then joining the colonizing current of the southwest Atlantic in the viceroyalty of Río de la Plata-Asunción and Buenos Aires. With Huancavélica and Potosí, silver (discovered in the Potosí Mountains in 1546) inundated Spain, Holland, and all of Europe. And by way of Portuguese land routes and ships, the colonizing current eventually reached China, stretching from Acapulco to Manila. Towards the north, the Latin American colonial world expanded into Central America, continental Aztec Mexico, and the realm of the Yucatecan-Guatemalan Maya. Finally, the conquering current moved north, towards the mines of Durango and Saltillo, towards California.

By $1620,{ }^{20}$ all of the Latin American political organization, with its viceroys, audiencias (appellate courts), capitanias generales (colonial military and administrative jurisdictions not under the charge of a viceroy), town councils, etc., had been put in place. The ecclesiastical organization, with more than thirty-five dioceses (the diocese of Durango in the north and the diocese of Buenos Aires in the south were founded this year), remained practically unchanged until the end of the eighteenth century. The Latin American colonial civilization would come to organize great universities of the rank of Salamanca (in 1553) as well as tens of university colleges and theological seminaries. ${ }^{21}$ The "lettered city" was Baroque in the seventeenth century and entered the Enlightenment in the eighteenth.

In 1610, when arrivals from the South were reaching the far north of Mexico (the far north of Latin America), the Mexican city of Santa Fe was founded in "New Mexico" (just as Mexico was "New Spain"). In considering the southern territory currently occupied by the United States, we contemplate what was the northern

\footnotetext{
${ }^{20}$ Paradoxically, this is also the year that the Pilgrims arrived in the north.

${ }^{21}$ At Harvard, there is a plaque in front of a statue of the founder that reads: "Since 1636, the first university of America." However, in 1536 the first American center of philosophical and theological studies, the Colegio de Santa Cruz in Tlatelolco (now part of Mexico City), was founded by the Dominicans. In 1540, in Tiripetío, Michoacán, Alfonso de la Vera Cruz founded the first Augustinian school. In the year 1553 just mentioned, the universities of Lima and Mexico were founded with prerogatives equal to those of Salamanca, Paris, Oxford, and Cambridge, in philosophy, theology, law, and medicine. Hispanos can claim, on behalf of their Latin American "brothers," to have inaugurated university studies on the continent.

[Dussel is technically wrong about the inscription on the plaque at Harvard, which reads "John Harvard-Founder-1638." To further complicate matters, the plaque itself is factually incorrect and is even known on campus as "The Statue of the Three Lies," since 1) the figure depicted is not John Harvard but rather a student from the nineteenth century used as a model; 2) John Harvard was not the founder but rather an early financial contributor after whom the school was named; and 3) Harvard was not founded in 1638 but rather in 1636. Of course, while Dussel is technically wrong about the inscription and while the inscription itself is inaccurate, Dussel is certainly right to question Harvard's (or any other U.S. university's) claim to being the first institution of higher education in the Americas. - TRANs.]
} 
region of the Latin American world - a world already more than a century old by then, with all of its libraries (like Puebla's Palafoxiana), printing presses, artistically imposing cathedrals, grand urban palaces, splendid fortified ports (like those of Havana, San Juan de Ulúa, and Cartagena de Indias), roads, aqueducts, haciendas, sugar refineries, etc. All of these institutions are prior to the origin of the Anglo-Saxon world in the American continent with the arrival of the Pilgrims in 1620. The Jesuit reductions and Franciscan missions in Texas, for example, tell us of the presence of hispanos in the far north of a Latin America that, from Patagonia, kept expanding northward beyond the Rio Grande/Río Bravo.

The hispano is, then, a Latin American, a "Latino," who, like the tip of an iceberg, is supported by an immense cultural mass that lies hidden underwater in the shadow of history. They are a population of more than four-hundred million citizens who, like the Visigoths bound for the Byzantine Roman Empire, began crossing their own Danube (the Visigoths were also "wetbacks" moving towards the south, the hispanos towards the north). So these Northern Latin Americans are conscious of having been in these lands since before the occupation of the desert, before anyone would cross the Appalachians, spread out by way of the Mississippi River, or reach Texas or California from the east. Hispanos/as are the Latin American brothers/sisters of the north, a Latin American nation to be considered as such.

\section{The "Fourth of Worlds." The Afro-Caribbean, Another Hispano}

In their "world," hispanos have yet another world of extreme vitality and antiquity. It originated in 1520 in Hispaniola when the conquistadors finished extracting gold from the rivers, finished off the indigenous Taínos in like fashion, and began the sugar cycle, for which they brought the first African slaves from Spain and later directly from West Africa (see Blackburn). Thus was born the "world" of the exiled Afro-Caribbeans, which spread throughout all the islands as well as the east coast of Central America, the north of Venezuela and Colombia, the coasts of the Pacific down to Guayaquil in Ecuador, and Portuguese Brazil, where sugar and other tropical products became the most prized of the Luso-Brazilian world.

The Afro-Latin American grew up creating culture, religion, myth, and rhythm while doing the interminable work that their inhuman owners demanded. They survived thanks to their music, their dance, their spirits (orishas), and their amazing fortitude. The Puerto Ricans were the first Afro-Caribbean population to arrive in New York at the start of the twentieth century after the United States annexed the three Spanish island colonies of the Philippines, Cuba, and Puerto Rico in 1898. All hispanos adopted the rhythms of the Afro-Caribbean as their own. Hispanos of indigenous background and white criollos learned the harmonious cadences of the African drum. For this reason, the racist questions posed at the North American university - “Are you African (not Hispanic)?”- makes little sense, because the Afro-Caribbean is African and also hispano. Hispanicity neither negates nor confuses africanicity. It is another "world" (the fourth) that contributes to hispanic consciousness in the United States. They are Latino-Caribbeans, Afro-Caribbeans from Puerto Rico and the Dominican Republic with their "salsa," Cubans with their ceremonies of Santeria, Haitians with their Voodoo drumbeat, and Brazilians with their Macumba and Candomblé. The hispano is African as well, with beau- 
tiful eyes (often Eastern from his/her "mother") and sensual African lips, moving his/her hips in the dance as only a "Latino" could. This is the complexity created "in-between" the borders of many worlds, "in-between" the interstices of many cultures.

\section{The "Fifth of Worlds." The Far South of the North}

England, the British Isles, has a history different from that of Spain and Portugal. Antiquity and the European Middle Ages separate them. The Franciscans founded Oxford and Cambridge. The contingent "will" of Duns Scotus and the empiricism of the Bacons tell us of a cultural tradition distinct from that of the Dominicans, a tradition more inclined to the continental "intelligence" of Paris or Salamanca. Baroque Catholicism had little to do with Anglicanism, democratic Presbyterianism, or utopic Puritanism. The absolute Spanish monarchy, fortified by American silver, defeated the nascent Spanish bourgeoisie in 1521 at the Battle of Villalar. Moreover, millions of Jews who should have been the internal financial class of the Spanish empire were thrown out and replaced by foreigners, Renaissance Genovese merchants. In contrast, the weakness of the English monarchy permitted the first triumphant bourgeois revolution in the seventeenth century, and it was this same bourgeoisie that took charge of organizing the parliamentary state, supporting commerce, and deploying the colonial structure of the growing English empire (which would slowly replace the Iberian powers beginning in the seventeenth century). The anglo projected the growing British splendor of the seventeenth and eighteenth centuries back into the past and carefully hid the sixteenth century in the shadows, whereas the hispano must begin with the sixteenth century in order to interpret himself/herself positively and resist humiliation and domination.

In America, the first anglo-saxons were preceded by the Dutch. "New England" had been "New Holland," and "New York" had been "New Amsterdam." Thus, the primitive utopian communities that de Tocqueville admired so much, which avoided an England under the model of Hobbes's Leviathan (the absolute State), were already modern in the spirit of the "second" Early Modernity (of Amsterdam, London, and Edinburgh). In the eighteenth century, the North Americans creatively assimilated the Enlightenment and carried out "their" Industrial Revolution, not in order to diminish the proportion of wages in the value of the product but rather to permit small, free owners better production. The colonies in New England thus participated in the origin of capitalist, liberal, and industrial Late Modernity, and had no other industrial or military power on the American continent that could compete with them at their level. Their expansion was a matter of time.

The communities of the thirteen colonies of the northeast Atlantic coast, emancipated from the English yoke in 1776, began to occupy the Mexican territory towards the west (the long journey towards the "far West," which commenced by way of Louisiana-also originally a part of New Spain-and continued towards the south with Texas and the west through Arizona, New Mexico, and California). They incorporated not just the territories but also the hispanic population, which, having come from before, remained trapped inside a new world unknown to them, a world that came from the northeast: the world of the United States of North 
America. This "inclusion"- which would be continued by a slow hispanic dispersion from the south towards the north during a long century-would have all the characteristics of an "expulsion" (like that of the people elected under Joshua, who defeated the Canaanites at Jericho, but now with Indian or Mexican faces: hispanos). ${ }^{22}$ This expulsion was not on behalf of foreign Europeans but now rather on behalf of the Americans from the north, who would expand by occupying territories and managing the hispanic populations that remained in the south.

The included populations were defenseless, without protection. Consider the protagonist figure of priest Martínez (see Dussel, Fronteras), trained in the seminary of Durango in Mexico, parish priest of Santa Fe in New Mexico. He was elected as a delegate to represent his province in Mexico City on various occasions, then was part of the independent assembly of New Mexico as an autonomous state, and finally served as a representative of New Mexico in Washington. As a Mexican Catholic priest in rebellion against the management of the Church by "foreigners" (not hispanos), he would be excommunicated by Bishop Lamy, who was of French nationality and did not understand the hispanic community, which made up the majority of the Catholic population there. Lamy was a bishop named by a Vatican that trusted the North American government more than the Mexican one. Thus, the hispanos remained a people "like sheep without a shepherd."

Over the course of a century, from 1848 until the end of World War II (1945), the hispanic people were ignored, oppressed, eliminated. Their language was prohibited. By their participation as soldiers in this war and in those that followed, by the growth of their population, by the massive Puerto Rican presence in the East, the Mexican presence in the Southwest, and the Cuban presence in Florida, the political importance of the hispanic community could no longer be silenced. The social and artistic Chicano movement, the syndicalism of people like César Chávez, the presence of "Fathers" and "Mothers" (priests and nuns) in the Catholic Church as well as the naming of many hispanic bishops, the appearance of political, commercial, intellectual, and artistic leaders has given the hispanic community the face of the largest minority in the United States. Mobilizations like those achieved against Proposition 187 in California have already demonstrated a community becoming conscious of its rights.

But the future is by no means guaranteed. The complex, rich, and "American" culture of hispanos needs to be creatively developed by acquiring greater political autonomy and refusing to jump on political bandwagons without first demanding conditions for the development of their communities. In fact, hispanos are now crucial to the election of the leaders of the United States because of their organized presence in Florida, New York, Chicago, Texas, and California. This is a historical opportunity to enrich the education of the members of the community, and

\footnotetext{
${ }^{22}$ The hispanic thinker from Texas, Vergilio Elizondo, shows how the discourse of liberation of Moses leaving Egypt with the former slaves (and by extension, the utopian-Christian communities that fled England or Ireland, poverty and persecution, in order to enter the "Promised Land" of the "God of slaves") is transformed into the contrasting discourse of appropriation. Joshua and the former slaves take up this discourse in order to justify the conquest of the "wilderness," that is, the land that they appropriated in the name of the "God of armies." See Elizondo. This discourse would remain permanently in the United States, from the occupation of the "far West" to George Bush's war against terrorism in the present, inspired by the "Western Design" of Cromwell, by "Manifest Destiny" and the Monroe Doctrine, and by the narratives of Fundamentalist Christian, North American expansionism.
} 
these remarks might serve as a rough draft for a course, a seminar, a book of cultural history, or a sketch to teach the hispano to become conscious of his/her own millennial, centennial history.

Hispanos need Latin America because the nutritive "roots" of their world lie there. They need the vital reserve of millions of "brothers/sisters" who press northward out of a contagious hope to escape their poverty. And Latin America needs hispanos. We do not need hispanos who, upon making themselves present in the south (for example, in commercial, military, or diplomatic roles), speak the language of Latin American culture in order to impose the imperial Will to Power. We need them to make present an American culture, that of the south, in the great country of the north. This culture can show the North American citizen other continental horizons and impart an increased responsibility for the poverty of millions and for populations who are not just markets but dignified human beings. It has fallen to us to inhabit this American continent, that of the south and that of the north. We need hispanos in order to learn how to live with a diverse, hostile, aggressive anglo-saxon culture whose rationality is founded almost exclusively in the competition of homo homini lupus. But its rationality also has immense critical reserves with which we must organize a front in order to save the life of humanity today amidst the risk of collective suicide.

National Autonomous University of Mexico

\section{Works Cited}

Bhabha, Homi. The Location of Culture. London: Routledge, 1994.

Blackburn, Robin. The Making of New World Slavery: From the Baroque to the Modern 1492-1800. London, Verso, 1999.

Dussel, Enrique. El encubrimiento del Otro: Hacia el origen del mito de la modernidad. Madrid: Nueva Utopia, 1993. (Trans. as The Invention of the Americas. New York: Continuum Publishing Group, 1995.)

- Ética de la Liberación en la edad de la globalización y la exclusion. Madrid: Trotta, 1998. (Trans. as Ethics of Liberation in the Age of Globalization and Exclusion. Durham: Duke UP, forthcoming.)

- Fronteras: A History of the Latin American Church in the USA since 1513. San Antonio: Mexican American Cultural Center, 1983.

- Hipótesis para el estudio de Latinoamérica en la Historia Universal. Resistencia: Universidad del Nordeste, 1966.

- A History of the Church in Latin America. Grand Rapids: Eerdmans, 1981.

Elizondo, Virgilio. Galilean Journey. The Mexican-American Promise. New York: Orbis, 1983.

Heidegger, Martin. Being and Time. New York: Harper and Row, 1962.

Schmitt, Carl. Der Begriff des Politischen. Berlin: Dunker und Humblot, 1966.

Wallerstein, Immanuel. The Modern World System. New York: Academic Press, 1974. 


\section{Comparative Literature 61.3}

Abstract (Article)

ENRIQUE DUSSEL

\section{“'Being-in-the-World-Hispanically: A World on the 'Border' of Many Worlds”}

The present essay offers an interpretation of hispanos (Latin Americans and U.S. latinos) as historically, culturally, and geographically located "in-between” many worlds that combine to constitute an identity on the intercultural "border.” To illustrate how hispanos have navigated and continue to navigate their complex history in order to create a polyphonic identity, the essay sketches five historical-cultural "worlds” that come together to form the hispanic "world.” 
Copyright of Comparative Literature is the property of Duke University Press and its content may not be copied or emailed to multiple sites or posted to a listserv without the copyright holder's express written permission. However, users may print, download, or email articles for individual use. 